\title{
ASM Handbook Series on Heat Treating Expands to Four Volumes
}

(C) Springer Science+Business Media New York and ASM International 2013

The recently-released Steel Heat Treating Fundamentals and Processes is the first of four upcoming ASM Handbooks on Heat Treating. Under the direction of an editorial team, including Jon Dossett and George Totten as Volume Editors, Volume 4A includes extensive updates and additions for all major topics such as furnace atmospheres, vacuum systems, atmosphere control, gas carburizing, vacuum carburizing, gas nitriding and nitrocarburizing, plasma nitriding, quenching, and tempering (Figs. 1, 2, 3, and 4 ).

Additional volumes scheduled for publication include:

- Heat Treating of Irons and Steels (Volume 4B, 2014) covering heat treating of specific ferrous materials and component applications. Volume Editors: Jon Dossett and George Totten with a team of Division Editors

- Induction Heating and Heat Treatment (Volume 4C, 2014) covering all major aspects of induction science, technology, and applications. Volume Editors: Valery Rudnev and George Totten with a team of Division Editors

- Heat Treating of Nonferrous Alloys (Volume 4D, 2015)

These volumes update and expand ASM Handbook, Volume 4, Heat Treating, which was published in 1991.

Coverage in Volume 4A will include several topics with new stand-alone articles on:

- Microstructural analysis of heat treated steels

- Hardenability calculation of carburized steels

- Cleaning of steels for heat treatment

- Austenitizing, direct quenching, and quenching and partitioning

- Fundamentals of carburizing, high-temperature carburizing, and stop-off technologies
- Fundamentals of nitriding and nitrocarburizing

- Furnace controls, induction systems, probes for quench characterization, and quench agitation and system design

- Articles on specific quench processes such as: gas quenching, coat forming, inverse hardening, salt quenching, fluidized-bed quenching, water-gas quenching, die quenching, press quenching, and patenting

Volume editors Jon Dossett and George Totten said, "Articles on the fundamentals provide in-depth background on the scientific principles associated with steel heat treatment, while articles on the various heat treating processes take a more practical approach. Many sections have been expanded, such as the sections on fundamentals and processing methods for carburizing and nitriding of steels. Coverage on the hardenability of steels is expanded, and several new articles have been added on quenching fundamentals and processes."

Steven Lampman, content developer, Reference Publications, ASM International, said a highlight of the new volume is the article "Fundamentals of Nitriding and Nitrocarburizing" by E.J. Mittemeijer. Lampman described the article as "worth the book price for those who care about fundamentals." The article covers the following:

- Advent of Nitriding

- Nitrided/Nitrocarburized Microstructure, Thermodynamics, and Kinetics

- The Iron-Nitrogen Phase Diagram

- Nitriding Potential and the Lehrer Diagram

- Controlled Nitriding

- Carburizing Potential and Controlled Carburizing

- Controlled Nitrocarburizing

- Local Equilibria and Stationary States 
Fig. 1 Grain growth in conventional carburizing steels with increasing carburizing temperature. From the article "Plasma Carburizing" by Brigitte Clausen and Winfried Gräfen

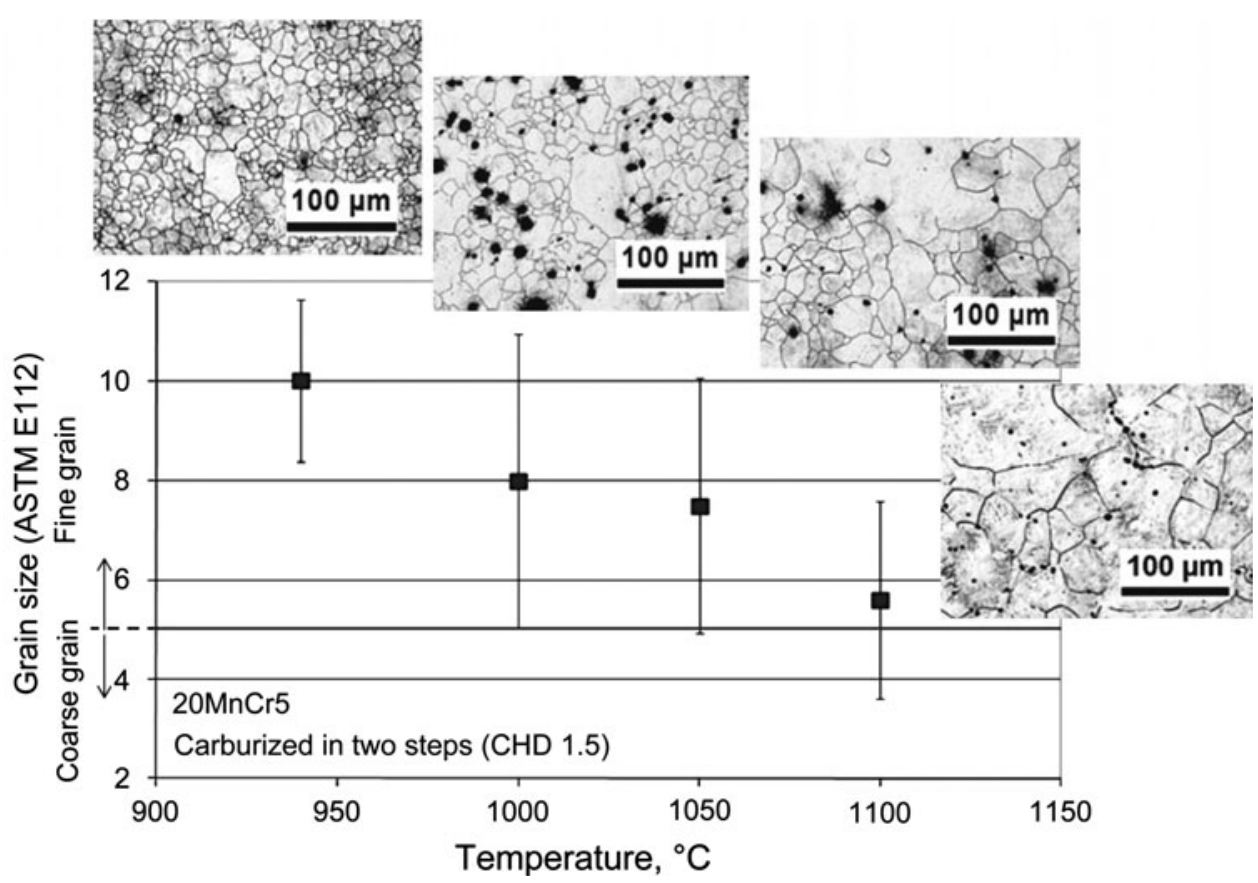

- Microstructural Development of the Compound Layer

- Kinetics of Compound-Layer Growth

- Microstructural Development of the Diffusion Zone

- Kinetics of Diffusion-Zone Growth

Contributors to Steel Heat Treating Fundamentals and Processes include:

\section{A.B. Ahmed}

McMaster University

Toru (Tohru) Arai

Consultant

Michael A. Aronov

IQ Technologies, Inc.

Manfred Behnke

NÜSSLE GmbH \& Co. KG

William J. Bernard, III

Surface Combustion, Inc.

Volker Block

Saarstahl AG, Germany

Rainer Braun

NÜSSLE GmbH \& Co. KG

Anja Buchwalder

Technical University Bergakademie Freiberg

Eckhard H. Burgdorf

NÜSSLE GmbH \& Co. KG

Lauralice de C.F. Canale

University of São Paulo

Charles Caristan

Airliquide

Madhu Chatterjee

Bodycote

\section{Brigitte Clausen}

Stiftung Institut für Werkstofftechnik, Bremen

Rafael Colás

Universidad Autónoma De Nuevo León

James Conybear

Metlab

Narendra B. Dahotre

University of North Texas

Craig Darragh

The Timken Company (Retired)

S. Dilip

Fluidtherm

Jon Dossett

Consultant

Edward (Derry) Doyle

RMIT University

Kevin M. Duffy

The Duffy Co.

Bernd Edenhofer

Ipsen Industries International $\mathrm{GmbH}$ (retired)

Jan Elwart

Bodycote European Holdings $\mathrm{GmbH}$

Imre Felde

University of Óbuda

Allen J. Fuller, Jr.

Amsted Rail Company, Inc.

Kiyoshi Funatani

IMST Institute (Consultant)

Weimin Gao

Institute for Frontier Materials, Deakin University 

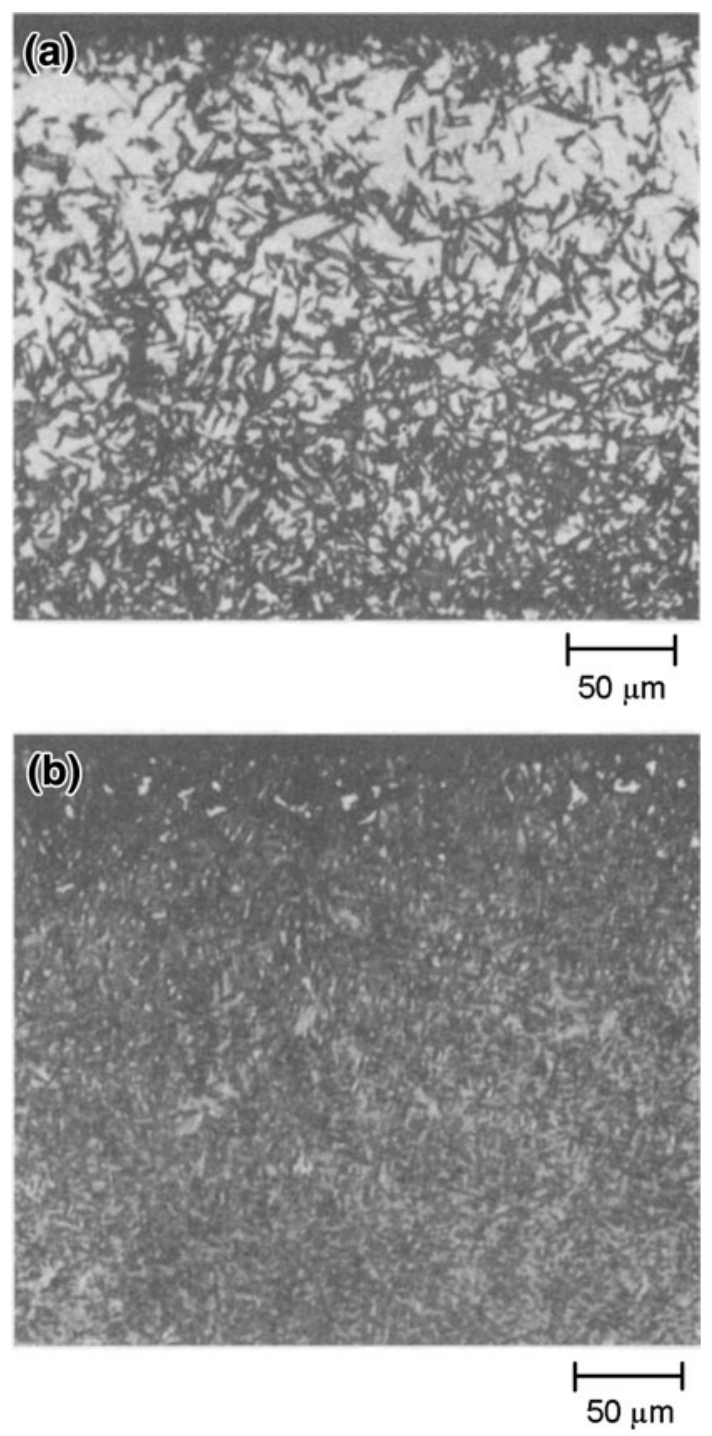

Fig. 2 Effect of low-temperature hold on retained austenite in carbonitrided 8617 steel bar. (a) Carbonitrided $4 \mathrm{~h}$ at $845^{\circ} \mathrm{C}$ $\left(1550{ }^{\circ} \mathrm{F}\right)$ in $8 \%$ ammonia, $8 \%$ propane, and remainder endothermic gas. Oil quenched and tempered $1.5 \mathrm{~h}$ at $150{ }^{\circ} \mathrm{C}\left(300{ }^{\circ} \mathrm{F}\right)$. Structure is tempered martensite (dark) and retained austenite. (b) Carbonitrided and tempered 8617 bar as in (a), except held $2 \mathrm{~h}$ at $-75^{\circ} \mathrm{C}$ $\left(-100^{\circ} \mathrm{F}\right)$ between quench and tempering. The structure is scattered carbide in a matrix of tempered martensite. Most of the retained austenite was transformed during low-temperature hold. Both $3 \%$ nital etch. Original magnification: $\times 200$. From the article "Carbonitriding of Steels" by Jon Dossett

\section{Robert J. Gaster}

Deere \& Company

\section{Winfried Gräfen}

Hanomag Härtol Gommern Lohnhärterei GmbH,

Germany

Jianfeng Gu

Shanghai Jiao Tong University

\section{David Guisbert}

QA Metallurgical Services LLC

\section{M.S. Hamed}

McMaster University

Larry Hanke

Materials Evaluation and Engineering, Inc.

Volker Heuer

ALD Vacuum Technologies GmbH

\section{Peter Hodgson}

Institute for Frontier Materials, Deakin University

Franz Hoffmann

IWT Bremen

\section{Ralph Hunger}

Bodycote European Holdings GmbH

Peter Hushek

Phoenix Heat Treating

Michael Ives

Park Metallurgical Corporation

\section{Scott Johnston}

Caterpillar Inc.

\section{J. Kalucki}

Nitrex Metal Inc.

Guldem Kartal

Istanbul Technical University

Gary D. Keil

Caterpillar Inc.

John R. Keough

Applied Process Inc.

Matthew T. Kiser

Caterpillar Inc.

Nikolai Kobasko

IQ Technologies, Inc.

Lingxue Kong

Institute for Frontier Materials, Deakin University

Maciej Korecki

SECO/WARWICK Corporation

Jim Laird

Consultant

B. Liščić

University of Zagreb

Thomas Luebben

IWT Bremen

Xinmin Luo

Jiangsu University

D. Scott MacKenzie

Houghton International

Dan McCurdy

Bodycote

Jim Malloy

Kolene Corp.

Mohammed Maniruzzaman

Caterpillar Inc. 

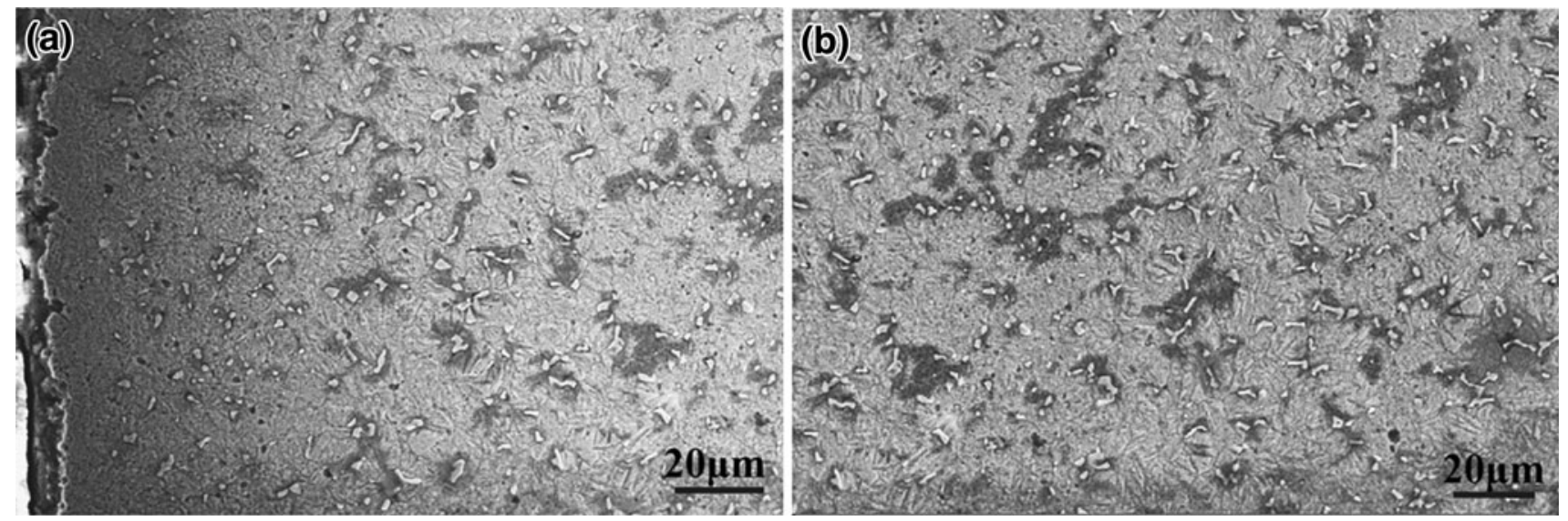

Fig. 3 Scanning electron microscope images of (a) the surface, and (b) the inside of the supercarburized layer treated by quenching and tempering. From the article "Supercarburizing" by J.Y. Shi

Fig. 4 Nitrided and postoxidized C15. Oxidation just began; iron oxides partially cover the porous compound layer below. Courtesy of IWT Bremen, Germany. From the article "Gas Nitriding and Gas Nitrocarburizing of Steels" by K.-M. Winter and J. Kalucki

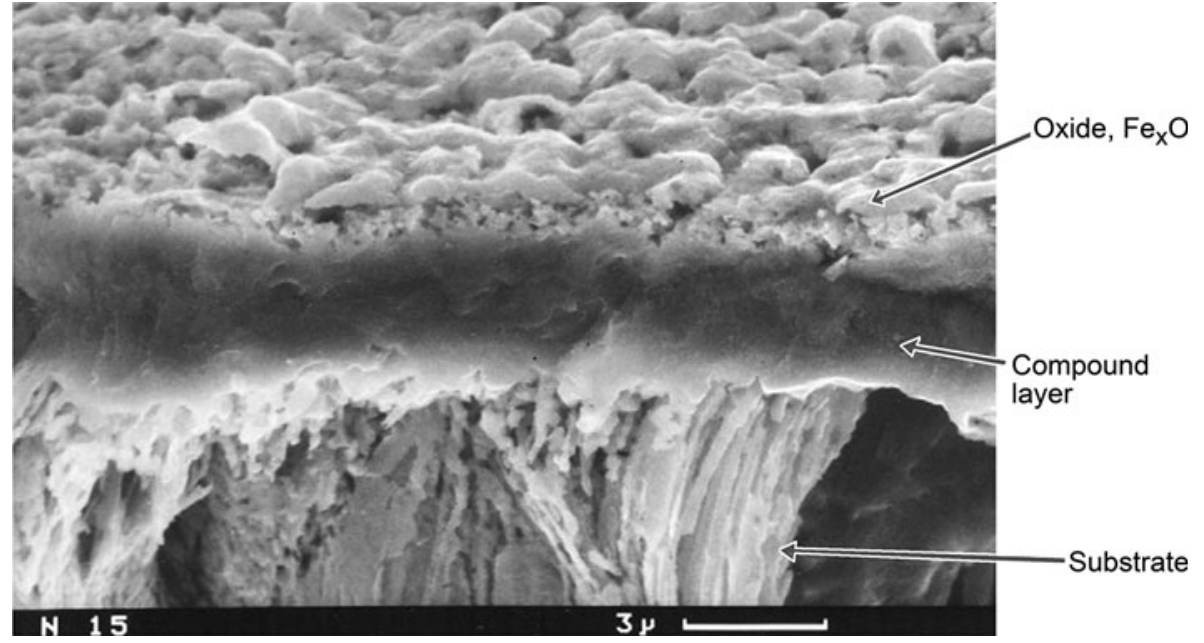

Božidar Matijević

Quenching Research Centre

L.L. Meekisho

Portland State University

\section{E.J. Mittemeijer}

Max Planck Institute for Intelligent Systems (formerly

Max Planck Institute for Metals Research)

B. Hernández-Morales

Universidad Nacional Autónoma de México

Aaron Muhlenkamp

The Timken Company

Fahrettin Ozturk

Nigde University

\section{George Pantazopoulos}

ELKEME Hellenic Research Centre for Metals S.A.

Renata Neves Penha

Universidade de São Paulo

Joseph A. Powell

IQ Technologies, Inc.
Narayan Prabhu

National Institute of Technology, India

Mark Ratliff

Avion Manufacturing

Arthur Reardon

The Gleason Works

Thomas Risbeck

The Timken Company

Barbara Rivolta

Politecnico di Milano (Polytechnic Institute

Milan)

Olga K. Rowan

Caterpillar Inc.

Valery Rudnev

Inductoheat Incorporated

Satyam S. Sahay

John Deere Asia Technology Innovation Center

S. Santhanakrishnan

Indian Institute of Technology Madras 


\section{Peter Schiefer}

Ford-Werke GmbH

Michael J. Schneider

The Timken Company

Juyan Shi

Taiyuan University of Technology

Saša Singer

University of Zagreb

Mark Sirrine

Flame Treating Systems

Richard D. Sisson, Jr.

Worcester Polytechnic Institute

Marcel Somers

Technical University of Denmark

John G. Speer

Advanced Steel Processing and Products Research

Center, Colorado School of Mines

Heinz-Joachim Spies

Technical University Bergakademie Freiberg

Bill Stofey

National Polymer Laboratories and Development Co.

George E. Totten

Portland State University
Eva Troell

Swerea IVF AB

André Tschiptschin

Universidade de São Paulo

David Van Aken

Missouri State University

Jan Vatavuk

Presbiterian University Mackenzie

Li Wang

Automotive Steel Research Institute, R\&D Center

Dale Weires

Boeing

K.-M. Winter

Process-Electronic GmbH

Roger Wright

Rensselaer Polytechnic Institute (Retired)

Rolf Zenker

Technical University Bergakademie Freiberg

Craig Zimmerman

Bluewater Thermal Solutions

Tim Zwirlein

Caterpillar Inc. 